\title{
Experience from three years of local capacity development for tsunami early warning in Indonesia: challenges, lessons and the way ahead
}

\author{
H. Spahn ${ }^{1}$, M. Hoppe ${ }^{1}$, H. D. Vidiarina ${ }^{1}$, and B. Usdianto ${ }^{2}$ \\ ${ }^{1}$ German Technical Cooperation (GTZ), Jakarta, Indonesia \\ ${ }^{2}$ German Technical Cooperation (GTZ), Yogyakarta, Indonesia
}

Received: 11 February 2010 - Revised: 31 May 2010 - Accepted: 1 June 2010 - Published: 2 July 2010

\begin{abstract}
Five years after the 2004 tsunami, a lot has been achieved to make communities in Indonesia better prepared for tsunamis. This achievement is primarily linked to the development of the Indonesian Tsunami Early Warning System (InaTEWS). However, many challenges remain. This paper describes the experience with local capacity development for tsunami early warning (TEW) in Indonesia, based on the activities of a pilot project. TEW in Indonesia is still new to disaster management institutions and the public, as is the paradigm of Disaster Risk Reduction (DRR). The technology components of InaTEWS will soon be fully operational. The major challenge for the system is the establishment of clear institutional arrangements and capacities at national and local levels that support the development of public and institutional response capability at the local level. Due to a lack of information and national guidance, most local actors have a limited understanding of InaTEWS and DRR, and often show little political will and priority to engage in TEW. The often-limited capacity of local governments is contrasted by strong engagement of civil society organisations that opt for early warning based on natural warning signs rather than technology-based early warning. Bringing together the various actors, developing capacities in a multi-stakeholder cooperation for an effective warning system are key challenges for the end-to-end approach of InaTEWS. The development of local response capability needs to receive the same commitment as the development of the system's technology components. Public understanding of and trust in the system comes with knowledge and awareness on the part of the end users of the system and convincing performance on the part of the public service provider. Both sides need to be strength-
\end{abstract}

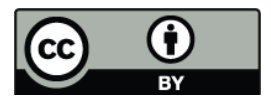

Correspondence to: H. Spahn (harald.spahn@yahoo.de) ened. This requires the integration of TEW into DRR, clear institutional arrangements, national guidance and intensive support for capacity development at local levels as well as dialogue between the various actors.

\section{Introduction}

The devastating disaster caused by the 2004 tsunami was the starting point for a huge effort in tsunami preparedness in Indonesia and other countries around the Indian Ocean. Five years after the disaster, much has been achieved. However, major challenges remain. Drawing from the experience of more than three years of support for local capacity development for TEW and preparedness in three pilot areas in Indonesia, this paper describes, from a practitioner's perspective, the challenges in developing an effective "last mile", and offers approaches and answers for capacity building at local levels.

Since mid 2006, the pilot project "Capacity Building in Local Communities" (GTZ-GITEWS) has engaged in the development of appropriate warning mechanisms and tools for tsunami preparedness and response to warnings. The project is implemented by the Deutsche Gesellschaft für Technische Zusammenarbeit (GTZ) GmbH (German Technical Cooperation) within the German-Indonesian Cooperation for a Tsunami Early Warning System (GITEWS) (Rudloff et al., 2009), together with its Indonesian partners at national (State Ministry for Research and Technology - RISTEK, and the Indonesian Institute of Sciences - LIPI) and local levels (local government institutions and civil society organisations). For Indonesia, the major tsunami threat is that of near field (or local) tsunamis. Statistically, destructive local tsunami waves in Indonesia occur every two to three years (Hamzah,

Published by Copernicus Publications on behalf of the European Geosciences Union. 
2000). The very short travel times of local tsunamis from the source - a nearby epicentre - to the shore often limit warning and evacuation time to only a few minutes. Quick response by both communities and local authorities is vital to saving lives. Such rapid response requires long-term preparedness planning. It calls for standard procedures to make quick decisions, coordinate reaction and communicate clear guidance. Communities need to be aware of the hazard, and of the natural warning signs, and know how the Indonesian Tsunami Early Warning System (InaTEWS) can support them. Tsunami hazard maps and vulnerability data describe the local tsunami risk and enable evacuation planning and the set up of a local public warning system (Fig. 1). Ultimately, the way the system works and the strategy for reaction in the event of emergency needs to be explained through public education, outreach and awareness campaigns, actively involving those at risk in the preparedness process in order to build understanding and trust, and to increase response capability.

For most communities and local governments in Indonesia this is a very recent field of activity. Disaster Risk Reduction (DRR) is a new paradigm, officially introduced by the new disaster management law in 2007 (JTIC, 2010). The new National Disaster Management Agency (BNPB) was founded in January 2008. While most of the provincial disaster management agencies (mandatory by law) have been formally founded, most district and municipal governments have not established this new agency (not mandatory by law). As in every new field, the process of developing tsunami preparedness is still characterized by unclear references and a lack of human and institutional capacities at operational levels; in other words, by a lack of the awareness, expertise and skills necessary to support coherent planning. While in general, adequate public service delivery remains a challenge in Indonesia, DRR and TEW are often perceived as added burdens without adequate additional resource allocation. Often, they are not a priority because other issues, such as poverty reduction and overall development, are perceived as more important than putting a huge effort into preparedness for "waves" that might not occur in the near future. Lack of political will to engage in community-based preparedness, and animosity towards science and technology-based early warning represent additional hindrances. The often limited capacity of local government that makes it difficult for local authorities to play their role in the warning system, is often contrasted by strong engagement of civil society organisations. Ultimately, bringing together the various actors and building a multi-stakeholder cooperation for an effective and trustworthy TEW system is the key challenge.

Despite all these constraints, considerable progress has been made in the GITEWS pilot areas and beyond. This paper discusses the progress and the obstacles in greater detail and provides some solutions how to tackle the challenges for developing the end-to-end system and increasing response capacity.

\section{Defining capacity building/development}

Ever since a close link was established between capacity development and aid effectiveness in the Paris Declaration in 2005 (OECD, 2010), an international development cooperation agenda without capacity development has become unthinkable. The definition of capacity development (or capacity building) in this paper is based on the definitions used by the Development Assistance Committee (DAC) of the OECD, which read as follows (OECD, 2006, p. 12):

"Capacity is understood as the ability of people, organisations and society as a whole to manage their affairs successfully. (...) Capacity development is understood as the process whereby people, organisations and society as a whole unleash, strengthen, create, adapt and maintain capacity over time. (...) Promotion of capacity development refers to what outside partners - domestic or foreign - can do to support, facilitate or catalyse capacity development and related change processes."

Following the Paris Declaration, capacity development is primarily the responsibility of partner countries, with donors playing a support role. Donors - and therefore donor agencies such as GTZ - commit to align their analytic and financial support with partners' capacity development objectives and strategies, make effective use of existing capacities, and harmonise support for capacity development accordingly (OECD, 2010).

The development of capacities involves identifying development problems and designing and successfully implementing solutions. GTZ often characterises this as the "ability for proactive management", which is understood as the capability of stakeholders to effectively combine and coordinate political will, interests, knowledge, values and financial resources in order to achieve their own development goals and satisfy their own development needs. Capacity development is a holistic process through which people, organisations and societies mobilise, maintain, adapt and expand their ability to manage their own sustainable development. The promotion of capacity development by external partners is a key instrument used by development cooperation to enable people, organisations and societies to develop and expand their ability for proactive management. Capacity development is essentially a process that must be stakeholder driven and stakeholder owned, i.e. the stakeholders must strongly identify with and be strongly committed to the desired change. However, it is possible that this ownership might not arise until the reform - or change - (see "support to a change process" as the underlying project strategy, Sect. 3.3) process is under way; external partners can support and facilitate the emergence of ownership, and assume temporary co-responsibility while these processes are still ongoing (GTZ, 2007).

Capacity does not exist as an abstract or general quantity. It exists only in relation to concrete problems, challenges and needs. Certain types of problems can be solved more easily and more rapidly than others; more problematic are those of 


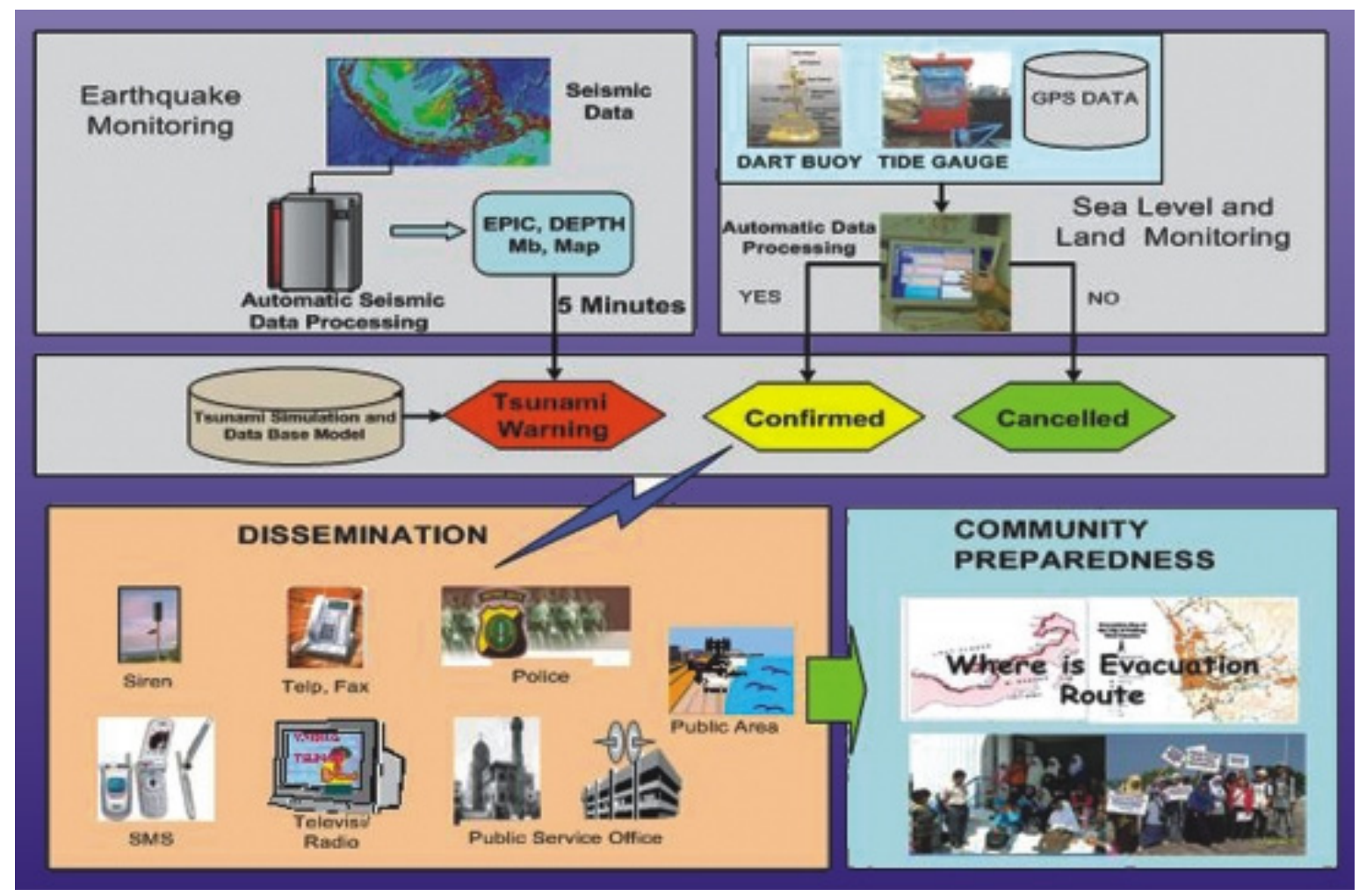

Fig. 1. The end-to-end concept of InaTEWS (source: IOC).

a long-term nature whose effects will only be felt in the future and whose causes are complex, such as the development of disaster awareness and sustainable institutional capacities. DRR is a new paradigm that has only recently been introduced in Indonesia; and TEW is part of the effort to reduce risk. Developing an end-to-end warning system calls for responses - and capacity development - from the local level right up to the national (and international) level. Capacity development is by no means a straightforward process. It is characterised by progress and success stories, but also by setbacks, conflicts and obstacles. Change processes of this kind will be successful only if they are systemic; only in exceptional cases will one-off interventions at the level of individuals or organisations be likely to achieve sustainable results.

\section{InaTEWS, GITEWS and capacity building in local communities}

\subsection{InaTEWS - an end-to-end early warning system}

InaTEWS is an end-to-end warning system. The monitoring and detection technology of InaTEWS is a combination of earthquake monitoring, sea level monitoring and land monitoring. The incoming data feed into a decision support system that enables the National Tsunami Warning Centre (NTWC) to assess the situation and disseminate a sequence of warning messages to selected interface institutions, local governments and national media stations. Local authorities need to make sure they can receive the warning, and are in charge of disseminating warnings and guidance to their communities at risk. They have the exclusive mandate to issue an official call for evacuation if necessary. Institutional and community preparedness and sufficient response capacity is the vital pre-condition for appropriate reaction to warnings and guidance.

\subsection{Capacity building within GITEWS}

To support the implementation of a tsunami early warning system (TEWS) in the Indian Ocean and especially in Indonesia (InaTEWS), the German government, through the Federal Ministry of Education and Research (BMBF), provided EUR 50 million for the development of the technical core elements of a tsunami early warning system. The German contribution to the system for detecting earthquakes and tsunamis in Indonesia relies on fast seismological network analysis and additional marine measurement procedures. Together with Indonesian and international partners, a concept has been developed under the guidance of the GFZ (German Research Centre for Geosciences) and RISTEK. This concept makes use of real-time data transfer, predetermined flooding scenarios in coastal regions, and direct warning reports (GITEWS, 2010). 


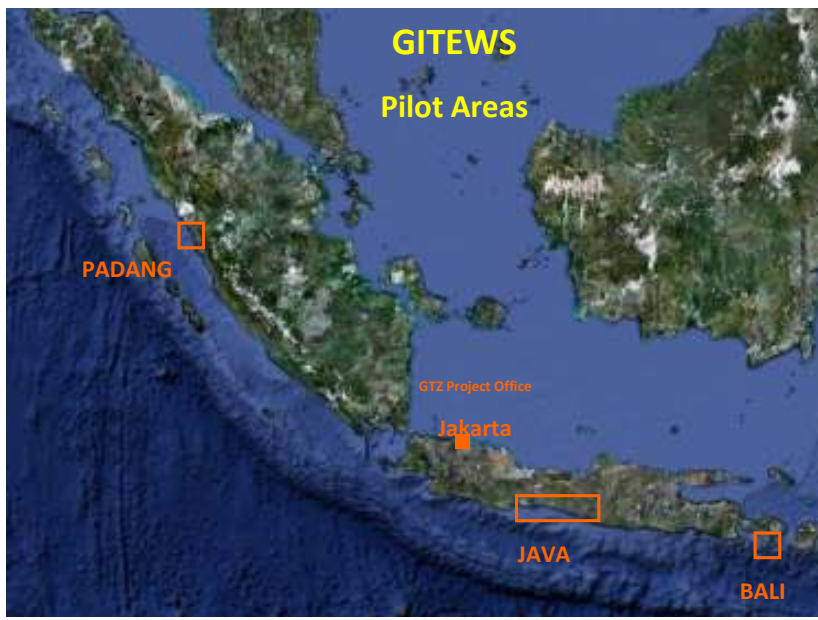

Fig. 2. Map of the GTZ-GITEWS Pilot Areas in Indonesia.

As part of the overall concept of the German-Indonesian Cooperation for a Tsunami Early Warning System, and in addition to the implementation of its technical components, GITEWS includes capacity building activities that target Indonesian partner institutions at various levels. The objective of GITEWS capacity building is that organisations involved in the tsunami early warning system develop human resources and coordinating mechanisms to ensure that all tasks related to the implementation, maintenance and further development of the system can be fulfilled. It also aims at supporting the set up of efficient organisational structures that will forward warnings, and clarifying the roles and responsibilities for decision-making in order to ensure effective tsunami early warning at national and local levels. In brief, GITEWS capacity building activities have three main objectives:

1. Establish higher-level education programmes and technical training programmes to provide the critical mass required to operate the system and to upgrade it in the future.

2. Establish organisational structures and inter-institutional communication.

3. Develop warning and tsunami preparedness mechanisms in up to three pilot areas (Fig. 2).

The "Capacity Building in Local Communities" project supports the development of mechanisms and strategies that enable people in risk areas to be promptly alerted in order to be able to quickly execute an adequate life-saving response. The so-called "last mile" is crucial to the effectiveness of the entire tsunami early warning system. Achievements in the technological sphere (i.e. upstream part of the system) will have no impact without a clearly defined warning chain (from national to local level), community awareness and preparedness, procedures and dissemination technology at the local level, and sufficient institutional and individual capacities. The project is limited to supporting the change process towards tsunami preparedness - implemented by the Indonesian partners within the pilot areas. This support includes the development and testing of tools and procedures for early warning and preparedness. The institutional integration and implementation of tsunami preparedness activities is the responsibility of local governments and stakeholders from civil society and the private sector.

\subsection{Capacity building in local communities: project strategy}

GTZ-GITEWS uses a piloting approach to develop sufficient tools and procedures for preparedness and early warning in Indonesia's tsunami-prone regions. The project supports its local partners in their preparedness process and simultaneously gathers experiences on how best to implement TEW at the local level. The project aims to share these best practices with national institutions that have the mandate to guide other tsunami-prone regions in their preparedness process, with the objective of building a consistent end-to-end early warning system throughout Indonesia (Fig. 3).

Cooperation with other international partners, such as UNDP, UNESCO-JTIC, IFRC, USAID, AusAID, and NOAA, and within the UNESCO-ICG Working Group on Community Preparedness is part of the project approach. The project concept is based on the UN-ISDR framework for early warning and focuses on preparedness as defined in the framework of DRR.

The pilot locations are Padang City in Sumatra, the province of Bali, the district of Badung in Bali, and the districts of Bantul (Yogyakarta), Kebumen and Cilacap (Central Java) along the southern coast of Java. Here, the project cooperates with local government institutions from various sectors (e.g. disaster response and civil defence as well as local planning boards). It also works together with actors from civil society, such as the Indonesian Red Cross, local NGOs, and the private sector (Fig. 4).

TEW is a public service and primarily a government responsibility. Nevertheless, it requires the involvement of all parts of society. To strengthen multi-sector and multistakeholder coordination for preparedness and to facilitate cooperation with GTZ, the local government partners in the pilot areas appointed local multi-stakeholder working groups. Through workshops, trainings and exercises, these groups develop appropriate solutions for TEW and preparedness at local government and community levels. These activities are facilitated by provision of technical advice, local subsidies for preparedness activities as planned and implemented by the partners, and some funding for testing dissemination technology and for other small infrastructure (such as warning signs). Additional funds are used to develop awareness material, and to conduct outreach and community awareness activities. 


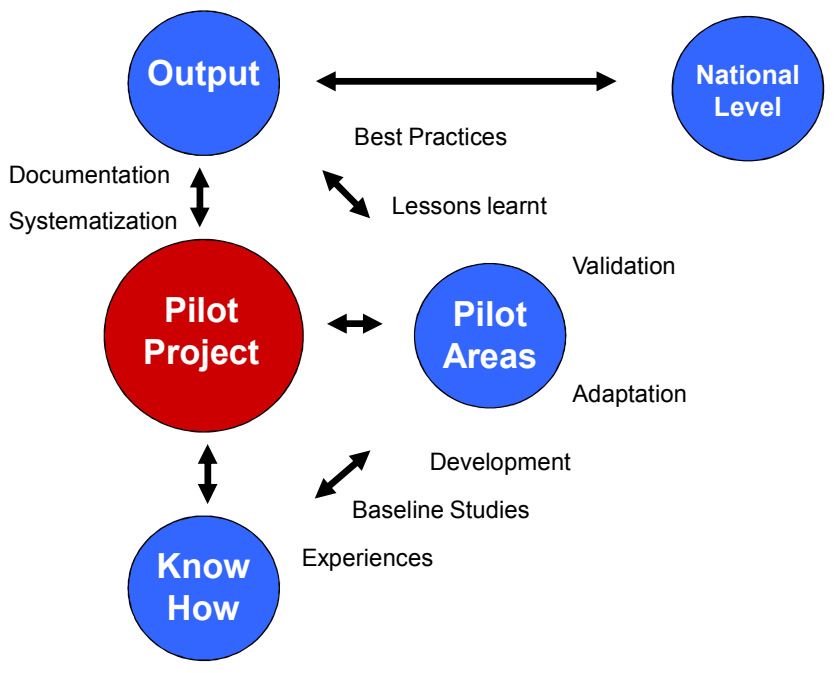

Fig. 3. Pilot project strategy.

The role of the project in this capacity building process and its mandate as a pilot project is three-fold (GTZ-GITEWS, 2010):

- GTZ introduces existing know-how on early warning and preparedness, in line with the overall requirements of InaTEWS and the local context of the pilot locations. These inputs include products from other GITEWS partners.

- The project assesses existing local strategies and discusses external know-how with its local partners. It provides technical advice on appropriate tools and procedures, helps clarify roles and responsibilities, and supports the local stakeholders in their implementation process. Overall, this process is characterised by a shift from disaster response to preparedness and risk reduction (change process). The mandate for the implementation of tsunami early warning and preparedness lies exclusively with the local partners, primarily the local governments, since they are in charge of warning and guiding their people in the event of emergency.

- As a pilot project, "Capacity Building in Local Communities" aims to gather experience and best practices for the implementation of tsunami early warning and preparedness at the local level in Indonesia. Thus, the project documents lessons and best practices, and provides them to national institutions in charge of strengthening the last mile. Once discussed and adopted, the project outputs can be used to support other tsunamiprone regions in their preparedness efforts (a complete documentation of the project's output will be available online by the of 2010: www.gitews.org/tsunami-kit).

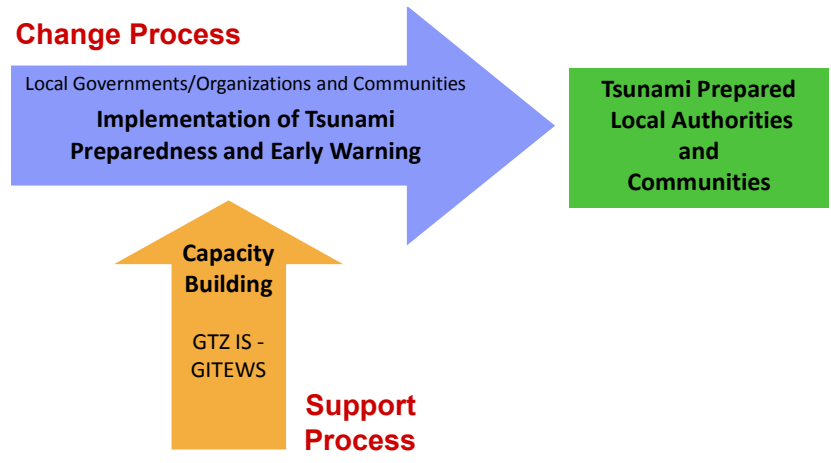

Fig. 4. Project approach at local level.

\section{Developing the end-to-end tsunami early warning system: challenges, lessons and the way ahead}

\subsection{A consistent end-to-end system requires effective governance, clear institutional arrangements and national guidance}

Warning systems are complex because they link many specialties - science and engineering, governance and public service delivery, disaster risk management, news media and public outreach. Therefore, the development and maintenance of a warning system demands the contribution and coordination of a wide range of individuals and institutions. Without the involvement of all stakeholders - authorities and government institutions from various sectors and at all levels, the communities at risk, NGOs and the private sector - the early warning system will not be effective (UNISDR, 2006; Sorensen, 2000).

Well-developed governance and institutional arrangements are the foundations upon which the four elements of early warning - risk knowledge, technical monitoring and warning service, dissemination and communication of warnings, response capability and preparedness to act by authorities and by those at risk (IFRC, 2009) - are built, strengthened and maintained. Effective governance that provides, a robust legal and regulatory framework and is supported by long-term political commitment, leadership and effective institutional arrangements, determines the sustainability of a warning system like InaTEWS. Governance needs to clearly delineate roles and responsibilities for the end-to-end system at all levels, provide resources, develop capacities, improve the quality of public service delivery, and encourage participation at local levels. Vertical and horizontal communication between early warning stakeholders strengthens coordination and is key to build a consistent system (IFRC, 2009; Lassa, 2008a; UNISDR, 2006).

Developing effective governance in general is still a major challenge for the Government of Indonesia. Conceived at independence as a federated republic, Indonesia developed 


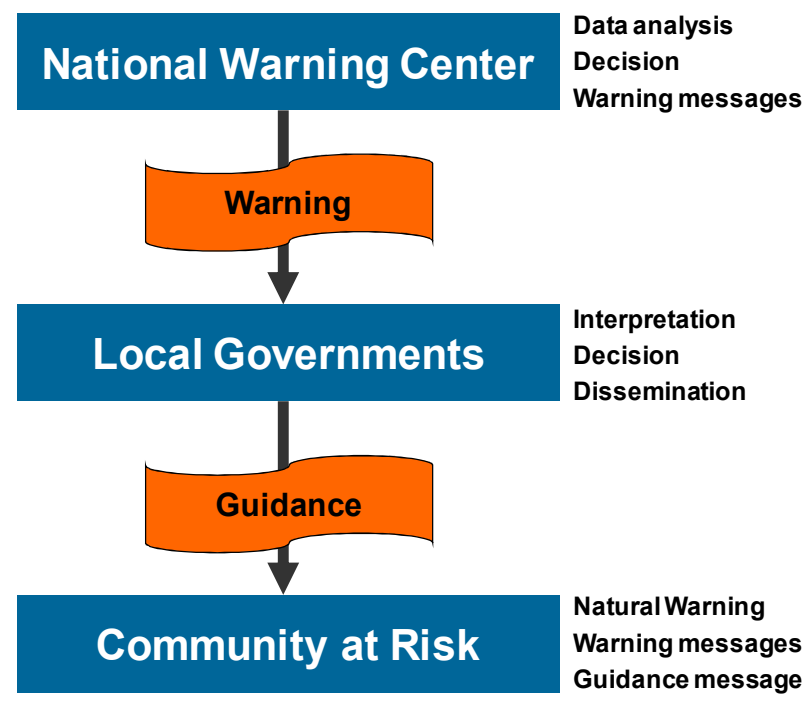

Fig. 5. Roles in InaTEWS.

into a highly centralised state with decision-making and control in the hands of the central government in Jakarta. The transition from a centralised government system to a decentralised system that began in 2001 delegates various mandates to province, district and municipal governments (including responsibilities for disaster risk management). However, managing the process of decentralisation involves no less for Indonesia than the reinvention of governance. Unsurprisingly, after almost a decade of decentralisation, Indonesian public administration at national and local levels still struggles to develop capacities and meet procedural and quality standards for public service delivery. Decentralisation will most probably remain a work in progress for the foreseeable future (GTZ, 2010).

These conditions have obvious consequences for the institutional arrangements and responsibilities as regards DRR. At the national level, Indonesia has proven its commitment to the shift from a paradigm of disaster response to one of risk reduction and preparedness by the introduction of the Disaster Management Law (No. 24/2007) and the establishment of the new National Disaster Management Agency (BNPB) in 2008. While most provinces have founded Regional Disaster Management Agencies (BPBD), most districts and municipalities have not yet established the institution. In the absence of clear national guidance, the implications of the Disaster Management Law for the implementation of DRR and TEW as part of DRR - at the sub-national levels still remain unclear to many local stakeholders. The existing BPBD struggle with a lack of skilled personnel and capacity development as well as ineffective recruitment processes. Even disaster management officials in leading positions often still lack understanding about what DRR actually signifies - not to mention the particulars of TEW (Thomalla et al., 2009; CSO, 2009).
While InaTEWS technology for earthquake monitoring, ocean observation and forecasting will soon be operational, the major challenge for the end-to-end early warning system is the definition of clear institutional arrangements and responsibilities for the long-term development of institutional and public response capability of the end-users of the warning system: the local authorities of and communities in tsunami-prone regions.

The integration of InaTEWS as a component of DRR, and the development of the capacity of the institutions in charge, i.e. the National as well as Regional Disaster Management Agencies, will determine the effectiveness and sustainability of the system. However, to date the transfer of responsibility for institutional and capacity development for the last mile from RISTEK as the coordinating agency for the development of InaTEWS, to BNPB as the national lead agency for DRR still lacks sufficient legal basis and institutional commitment.

Consequently, most local authorities in Indonesia still lack an understanding of their role in local preparedness planning for TEW. This includes an understanding of their role in the case of emergency (as defined by regional autonomy laws), i.e. to make a decision on how to react and to disseminate an official call for evacuation (if necessary) to their communities based on warnings from the NTWC (Fig. 5).

Several initiatives in various regions of Indonesia have strengthened the understanding of InaTEWS in general, and of the roles of national and local stakeholders as regards warning dissemination and response in particular. Amongst others, the Indonesian Institute of Science (LIPI) and the Ministry of Marine Affairs and Fisheries (DKP) have worked in different pilot areas to build local capacities. While the warning system has been developing over the years, annual tsunami drills have been conducted in a number of locations. Five years after the Aceh tsunami, the IOWave09 Exercise (an Indian Ocean wide tsunami drill) was conducted as an end-to-end drill in the Province of Aceh, where authorities and communities tested their response capacity. A task team, consisting of various national institutions including BMKG, RISTEK, and LIPI (together with UNDP), supported the local government in Aceh and other stakeholders in the development of decision-making and dissemination procedures as well as community outreach activities during the preparation of the drill. The drill created national, local and international momentum for the discussion on TEW and preparedness. The results of the drill's evaluation were used to refine these procedures (IOWave09, 2010).

Looking at the progress in some of the GITEWS pilot areas with regard to the warning chain and the clarification of roles and responsibilities, important steps forward have been taken. The district of Bantul (Java) tested its local disaster operations centre in charge of TEW, including SOPs, dissemination, evacuation plans and peoples' response capacity, in a tsunami drill in 2008, involving local authorities, several disaster management institutions and around 5000 residents in 
pilot villages. The evaluation of the drill led to an intense discussion with national stakeholders about the command chain and whether an official call for evacuation requires approval by the district head prior to dissemination. In fact, authorities in Bantul had mandated the operations centre to make a decision on whether to call for evacuation or not and to directly issue guidance to the public. This follows the logic of the decision-making SOPs, which translate standardised warning from the NTWC into standard response at the local level and take into account the short lead-time of near field tsunamis. Agreed and approved by local authorities, these procedures save time and bring the information to the people as quickly and direct as possible (GTZ-GITEWS, 2010).

The development of TEW in Bali accelerated with the construction of the province's emergency operations centre in 2009. The Governor made the centre a priority. Personnel received training on communication technology and procedures. A governor's decree now determines mandates and responsibilities with regard to TEW. The authorities delegate the warning service to the province's operations centre. This means that the provincial authorities - rather than each single district government - disseminate a call for evacuation directly to the public via tsunami sirens and public radio. This model might not be in line with the usual mandate of a provincial government but it simplifies the warning chain significantly and benefits those exposed to the tsunami threat. The move for one centralised operations centre also reduces overall costs for 24/7 operations and deals with the limited human resources in the region (GTZ-GITEWS, 2010).

The earthquake on 30 September 2009 in West Sumatra fortunately did not cause a destructive tsunami, nor did the NTWC issue a warning. The intensity of the event, however, caused fear of a tsunami. A survey, conducted by GTZ-GITEWS together with KOGAMI (Tsunami Alert Community, a local NGO) and with support from the Last Mile Project (partly implemented by UNU-EHS, United Nations University-Environmental and Human Security) as well as the city's BPBD, showed that only about $50 \%$ of 200 interviewees evacuated. The earthquake also triggered response in the city's disaster operations centre. The centre, since early 2009 a unit of the city's newly established BPBD, disseminated information from the NTWC that there was no tsunami threat via VHF radio around $5 \mathrm{~min}$ after the quake - however, not to a wider public. About $20 \mathrm{~min}$ later, the Mayor of Padang announced the information via the local state radio station of Radio Republik Indonesia - after he had finally received the information from the NTWC via SMS. Due to power outage and failure of several cellular phone networks, there was no contact between the operations centre and the mayor. The operations centre did not have the means - nor the mandate - for public dissemination. The lessons from the event led to a review of mandates, SOPs, and the dissemination system. A mayor's decree, introduced in April 2010, now regulates the mandate of the operations centre as public provider of warnings and guidance (a detailed account of the earthquake, institutional response and community reaction can be found in Hoppe and Mahadiko, 2010).

Despite this progress in some locations, the particulars of the role of local governments in TEW, and its implications for the institutional set up, human resources and budgeting requirements, are not yet apparent to most of the local governments of tsunami-prone regions in Indonesia. In particular, those that remain outside of the attention of previous or ongoing pilot project activities lack clear guidance for longterm preparedness planning for future tsunamis and their role in case of emergency.

In order to strengthen the local stakeholders of InaTEWS, the development of institutional arrangements and response capability to act needs to receive the same level of attention and commitment (as well as investment!) provided to the technological aspects of early warning (IFRC, 2009; Lassa, $2008 \mathrm{~b}$ ). While the uncertainty regarding the institutional arrangements of InaTEWS will not be solved in the short run, there is an urgent need for clear guidelines that define the linkage between national and local level within InaTEWS in a formal way. Such references need to build upon experience from the various piloting activities by the Indonesian partners and GITEWS. Besides other aspects of TEW and preparedness, including public education, hazard and risk assessments and evacuation planning, particular emphasis needs to be put on the promotion of an effective TEW chain. All actors in this chain - from the NTWC to the communities at risk need to clearly understand the overall design of the end-toend warning system, its warning scheme and messages, the roles of all actors, as well as their individual role, responsibility and rights.

Based on its experience working on the last mile, GTZGITEWS actively supports the preparation of a national tsunami warning chain guideline that provides clear guidance to local governments and other actors on the technicalities of linking to InaTEWS, and on how to establish procedures and build sufficient human and institutional resources for effective TEW and preparedness planning. Already the drafting process of such a document is expected to lead to clearer coordination among national institutions, and should accommodate the needs of local stakeholders. If widely disseminated and promoted, this document is considered a vital step towards establishing a more consistent and sustainable end-to-end warning system. The guideline will help to answer local stakeholders' questions and enable them to take action towards tsunami preparedness, and provide a reference for all actors involved in TEW in Indonesia. The National Agency for Meteorology, Climatology and Geophysics (BMKG) as the institution that operates the NTWC is committed to publish this warning chain guideline within this year. Local representatives from government and civil society in the GITEWS pilot areas will be involved in the drafting process. 


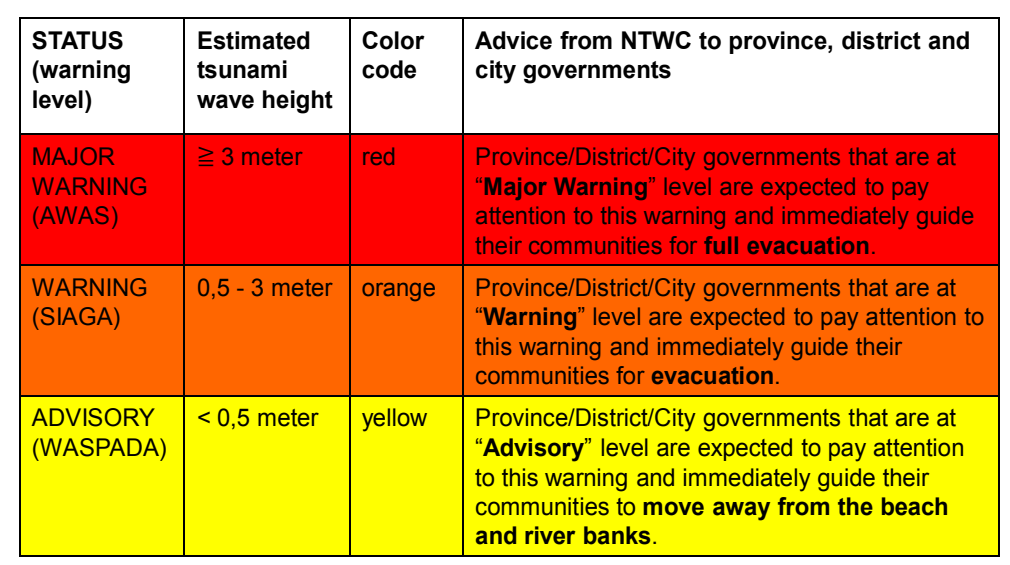

Fig. 6. Warning levels and advice as part of the warning messages from the NTWC (source: BMKG).

A formal, national guideline is one key to a more consistent system. Horizontal and vertical dialogue between tsunami-prone regions and between national and local levels of government is another. To promote such dialogue, GTZGITEWS set up a programme for exchange. Through crossvisits and a series of dialogues facilitated by the project, national stakeholders have had the opportunity to gain deeper insight into preparedness progress at district/municipal and province level. In turn, local stakeholders from the GITEWS pilot areas had the chance to get clarification on the warning system, roles and responsibilities and procedures from their national counterparts. Visits by local partners to the NTWC at BMKG and to the BNPB emergency operations centre helped to close the "gap" and build a better understanding of the end-to-end system at both levels. The exchange programme received a positive response from all participants because it provided a vital forum for discussing ideas, experience and challenges. Discussion on how to continue such dialogue in the future is ongoing (GTZ-GITEWS, 2010).

\subsection{Adjusting the system to the needs of the end user: clear warning and guidance messages for InaTEWS}

The ultimate goal of TEW is to reduce human fatalities and injuries. Key objectives in meeting this goal are the provision of timely and effective tsunami warnings and guidance through identified institutions and communication channels that allow individuals exposed to an imminent tsunami threat to take appropriate action, evacuate risk areas before a tsunami reaches the coast and save their lives (UNISDR, 2006). To be effective and useful to the "user" of the warning system, a warning has to be plausible and credible, clear and understandable. It needs to provide information about the threat level and its regional impact as well as time. Ultimately, a warning needs to provide guidance on what to do and on how those exposed to an imminent tsunami threat can protect themselves (Kunz-Plapp, 2008; Sorensen, 2000).
The actors in the tsunami warning chain can operate only within their legal mandate. The NTWC at BMKG cannot issue an official call for evacuation, which is the exclusive mandate of local government at district and municipal level. However, the warning products of InaTEWS have to serve the end users of the system. The information that comes out of the warning system has to make sense from a practical (rather than a technical or scientific) perspective at local level, and enable local authorities as well as the public to take immediate action. Experience in the GITEWS pilot areas shows that there is a need for 1) clearer and more instructive warning messages from the NTWC to local authorities, 2) the formulation of particular warning content for the media, in particular, television and radio stations that broadcast information to the public, and 3) the formulation of clear warning and guidance messages to be disseminated by local authorities to their communities at risk.

Given their limited capacities and expertise, and limited access to other information, local entities rely heavily on comprehensive warning information from the NTWC. Besides information on the threat level and its regional impact, it is clear advice that will help them to make appropriate and quick decisions in the event of emergency. Local authorities not only play an important role in transmitting the warning and providing guidance to the people at risk, but can also provide feedback to the warning provider about how they understand the warnings and how they might be made more actionable or comprehensible (IFRC, 2009).

Learning from experience in the pilot areas, GTZGITEWS, together with BMKG and other GITEWS partners (from GFZ and the German Aerospace Centre - DLR), promotes continuous discussion on the content of warning messages for InaTEWS in order to adjust the output of the system to local conditions and create an adequate warning scheme. Based on feedback from local representatives, BMKG has in the meantime incorporated an "advice" component in its 
messages that provides recommendations to local authorities on how to react to the warning (Fig. 6). However, discussion on the advice by BMKG needs to continue, in particular, with respect to the two-level approach for warnings and how these levels can be translated into local action (see Sect. 4.6).

In many - if not most - tsunami prone regions of Indonesia, institutional capacities and infrastructure for translating warnings into clear guidance to communities at risk are still very much limited. This means that there are no local sources of tsunami warnings. Research on public response to warnings shows that even in areas where public alerting systems are in place, people might look for additional information from other sources before they take action (Lindell et al., 2005; Sorensen, 2000). Here, national and local television and radio stations play a major role in providing additional sources of warning and getting information to the public.

A tabletop simulation during the preparation of the IOWave09 tsunami exercise that involved media representatives from national and local television and radio stations highlighted the importance of providing special warning messages to the media. In the evaluation of the tabletop exercise, media representatives came up with clear recommendations for the content of the message. The InaTEWS warning messages need be clear and understandable to the public, using non-technical language. They have to indicate what happened (earthquake) and describe regional threat levels (from a potential tsunami). Most importantly, the messages need to provide clear recommendations to the public on what to do. Due to the limited time available, the message format and content from the NTWC needs to be ready for immediate broadcast to the public without prior interpretation or technical adjustments (InWEnt, 2009). The discussion on the content of the media message between BMKG and several radio and television stations is currently ongoing. The results will be addressed in the drafting process for the national warning chain guideline.

Once local authorities receive warnings and advice from the NTWC, they need to quickly translate these into guidance and an official call for evacuation (if required). This requires clear procedures and technology. However, it also requires clear standard messages. The content of these messages needs to follow the warning information from the NTWC but requires adjustment to local conditions in terms of wording and language. Public education campaigns need to inform communities in tsunami prone regions about the warning messages and the guidance (including siren sounds) that they can expect in case of emergency (Kunz-Plapp, 2008; Gregg et al., 2007; Mileti, 2004). GTZ-GITEWS has been involved in intensive discussions on warning content with its local partners in Java, Bali and Padang. The result is an operations manual for TEW in local operations control centres that contains dissemination SOPs and various standard guidance messages for public information and alerting to be issued after an earthquake, depending on the actions that need to be taken (GTZ-GITEWS, 2010).

\subsection{Increasing public understanding of InaTEWS and how it can help to save lives}

"Did the warning system work?" is the question inevitably asked after a strong earthquake that is followed by a warning of a tsunami threat. This is a question not easily answered. The "system" consists of many parts, some of which might work and others not. Failure in any one of these parts can mean failure of the whole end-to-end system (IFRC, 2009). From the perspective of the last mile, a more pertinent question might be: "Did the warning reach the people on the coast in time and did they respond appropriately?"

The 7.3 earthquake southwest of Tasikmalaya (West Java) on 2 September 2009 (at around 14:55 LT), which fortunately did not cause a tsunami, provides us with an interesting case study. On that day, at about 14:58 LT, the National Tsunami Warning Centre in Jakarta issued a timely tsunami warning (based on seismic data) within $4 \mathrm{~min}$ of the tremor. The NTWC sent out the warning to local authorities (via SMS) and to the media. National television stations (SCTV, RCTI and TVONE) broadcast the warning shortly afterwards. A vital part of the warning system - the NTWC monitoring and warning service - worked (though the NTWC has yet to improve its capacity for dissemination via multiple channels).

In the district of Bantul, province of Yogyakarta, on the southern coast of Java, where TEW was introduced in 2006 and tested in a drill in 2008, the local disaster control centre took the decision to disseminate warning and guidance to the public along the coast about $10 \mathrm{~min}$ after the tremor. The centre's initial source of information was the television broadcast on SCTV. Subsequently, it obtained information from the Internet and a (forwarded!) SMS. Due to the magnitude of the earthquake and its distant location off the shore of the province of West Java, the local SOP indicated only a minor tsunami threat for Bantul and no need for an official call for evacuation. Consequently, sirens were not activated, but the announcement via (remotely operated) loudspeakers provided information on the earthquake and the possibility of a tsunami. People were told to "stay on alert" (Indonesian: harap waspada). The operations centre and Search and Rescue (SAR) personnel along the coast established immediate contact through VHF radio. SAR disseminated information at a tourist location on the coast (Parangtritis). At the same time, SAR personnel observed the sea (for natural warning signs) from higher ground. The warning was also communicated through the SAR "south-to-south" VHF communication network that provides a link with disaster personnel in neighbouring districts along the coast. Based on information from the NTWC that was broadcasted by SCTV and received through an Internet application by Air Putih (that immediately retrieves the latest earthquake information or warning from the BMKG server), the operations centre announced a cancellation message indicating that the tsunami threat was over and that people could return to their normal activities. Again, this announcement was made via the system of local 
loudspeakers installed at mosques and on siren poles, as well as at the SAR post, and could also be heard on VHF radio, about one hour after the earthquake (Usdianto, 2009).

Further evaluation of the event revealed several constraints. In some locations, coverage was limited and the voice quality of the loudspeakers was poor. The announcement by the operations centre did not include clear guidance for action (though indicated by the TEW operations manual and the standard text for announcements). People were only asked to "stay on alert" but not to "move away from beaches and rivers" as a measure of precaution. As exercised during the tsunami drill, people are supposed to clear beaches and riverbanks immediately after ground shaking and then search for further information from local authorities. The local residents pro-actively approached SAR personnel at the beach and local facilitators (who had conducted outreach activities prior to the tsunami drill in 2008) to get more information on the earthquake and the tsunami threat. Many had also heard the announcements from the loudspeakers. Though no detailed assessment was made, it has to be concluded that many people did not leave the beach - neither immediately after ground shaking nor upon receiving more information via loudspeakers. Local residents of Parangtritis (who live about 300-400 $\mathrm{m}$ from the coastline) went out of their houses when they felt the ground shaking and searched for additional information - which they got; however, it did not include clear guidance. Observations suggest that visitors who were actually on Parangtritis beach during the earthquake did not feel the tremor nor did they hear the announcements. We conclude that this inconsistent response is related to the difficulties with coverage and voice quality of the loudspeakers, the absence of other alerting devices (e.g. megaphones), the lack of instructive guidance from the operations centre, the fact that ground shaking was not felt by all, and a lack of public understanding and awareness (Usdianto, 2009).

While disaster management institutions in Bantul, with the support of strong political commitment, have worked on tsunami preparedness and TEW for the last four years, other communities along the southern coast of Java remain outside of tsunami preparedness activities and/or lack support from authorities. A more detailed assessment of institutional and community response in other districts along the coast that were directly exposed to the tsunami threat on 2 September 2009 is not available. However, the overall picture (as given by media reports, see below) shows that institutions were not prepared and did not react or disseminate guidance, and consequently people along the coast did not receive any warning.

These shortcomings can be explained by a lack of overall awareness, political will and leadership with regard to making TEW and DRR a priority. Coupled with that, the Regional Disaster Management Agencies are only just developing and the necessary expertise and human capacities are very limited. Discussions that followed the events of 2 September also revealed a general misperception of the early warning system. Even the renowned daily newspaper

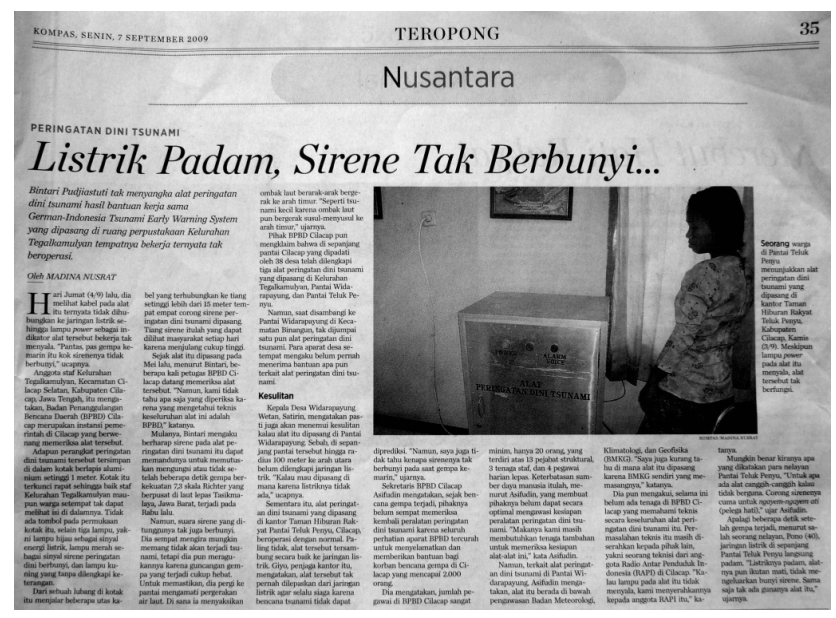

Fig. 7. "Electricity Down, Siren Did Not Sound..." (KOMPAS, 7 September 2009).

KOMPAS (7 September 2009) contributed to the impression that TEW is primarily about technology working, not human capacity (Fig. 7). By many, the "system" is seen as a network of technical devices rather than a system that in fact depends greatly on human capacities and skills, systematic preparedness planning, agreed procedures, decision-making capacity, and a common understanding of what to do and how to react. From a local perspective, the warning system is often (wrongly) perceived as a set of sirens that are directly connected to tsunami detection devices in the open sea. Sirens or loudspeakers will automatically sound and alert those at risk along the coast in the event that those devices detect tsunami waves. This view of the system is, of course, entirely incorrect and misleading, since the end-to-end warning system is equally about fulfilling roles and taking responsibility and decisions. This view seems to be rooted in a strong belief in science and technology as the ultimate solution. Indeed, at first sight InaTEWS comes across as high technology, which undoubtedly it is (in the upstream part). However, the human factor, as well as the need for preparedness planning, continuous public education, a sufficient local legal framework, coordination and agreements between stakeholders and human resources development in order to be ready in case of emergency, are still often neglected and ignored.

Early warning is a system, not a technology (IFRC, 2009), and the people at risk of tsunamis are the raison d'être of a warning system (Lassa, 2008b). Educating the public and the people at risk about the hazard, the warning system as a whole, local warning arrangements and how the system can help to save people's lives is key to its effectiveness. Even in places like Hilo, Hawai'i, whicht was repeatedly hit by destructive tsunamis in the past, there remains some uncertainty in the level of public understanding of the sirens and their implications for behavioural response. Hilo's community has been exposed to monthly tests of the sirens for more than 
25 years and descriptions of the system have been widely published in telephone books for at least 45 years. However, results from recent surveys show that public understanding of the meaning of the siren remains disturbingly low. This led to the conclusion that a major change is needed in tsunami education to increase public understanding of, and effective response to, both future official alerts and natural warning signs of future tsunamis (Gregg et al., 2007).

This example from Hilo highlights the current and future challenges for the end-to-end warning system in Indonesia, where efforts for public education on tsunami preparedness and TEW have started only in recent years. There are several key issues that need to be addressed in public tsunami education at all levels.

Explain the hazard, the warning system and what appropriate response means. Local governments and disaster management institutions are in a key position in InaTEWS. While the media broadcasts official warnings from the NTWC, local authorities are the entity that is mandated to make an official call for evacuation based on warnings from the NTWC. Public education campaigns need to inform people about the warning messages, their meaning and what they can expect in case of emergency. People at the coast do not have to wait for official alerts, but need to move inland and to higher ground immediately after a strong earthquake, due to the short wave arrival times of near field tsunamis, and then search for information pro-actively. Knowledge of natural warning signs needs to be strengthened. Experience from the Aceh Tsunami in 2004 (Smong in Simeulue, McAdoo et al., 2006; Lassa, 2008b) and the Solomon Islands Tsunami in 2007 shows how local knowledge of natural warning signs (strong earthquake and retreating seawater) saves lives when the right combination of education and topography, i.e. accessible high ground, come together. However, communities in broad coastal plains and/or with high population densities in urban agglomerations as in Padang (province of West Sumatra) would have severe difficulties evacuating the coast (McAdoo et al., 2008). Results from the recent study on the reactions to the earthquake in Padang suggest that public education needs to clearly distinguish between the two main natural warning signs of an impending tsunami. Half of the people interviewed in the survey ( 200 individuals) evacuated low-lying coastal areas in relatively short time as a reaction to the strong earthquake (15 min after the tremor, $83 \%$ of them had left). However, in the absence of other (official) information, many of those who did not evacuate rushed to the beach to see whether the seawater was retreating (Hoppe and Mahadiko, 2010). Official evacuation strategies should build upon ground shaking as the trigger for immediate response and official tsunami warnings and guidance to reinforce or cancel evacuation. Awareness campaigns have to strengthen the understanding that reacting to a strong earthquake with immediate evacuation is the appropriate response, but that waiting for the seawater to retreat, which confirms an approaching tsunami, is not. If, however, the tremor from a distant earthquake is not felt and no official alert is received, an immediate response to the observation of retreating seawater provides the last chance to escape.

Openly address uncertainty. InaTEWS has to deal with near field tsunamis as the most frequent tsunami threat for the country's coasts. A first warning from the NTWC is issued based on the earthquake parameters. As planned for 2010, the warning service of the NTWC will incorporate predetermined flooding scenarios and the results of a decision support system. This might increase the accuracy of the warning system over time. However, whether a tsunami was actually generated or not cannot be determined only based on seismic data and scenarios. Additional ocean observation data is required. Nevertheless, as data from buoys and tide gauges will hardly be available within the first 5 min after an earthquake (the official time limit for the NTWC to issue the first warning) it is still uncertain whether a tsunami is on its way or not. Due to this uncertainty several "false alarms" were issued in the past and false warnings will also be disseminated in the future. Research in the United States has revealed that repetitive false alarms may decrease response; however, the likelihood of people responding to a warning is not diminished by what has come to be labelled as the "cry wolf" syndrome if the basis of the false alarm is understood (Sorensen, 2000). The only ways to maintain public trust in and credibility of the warning system is to 1) further improve the accuracy of the warning service and 2) to embrace uncertainty (Mileti et al., 2004). Indonesian media reports after the earthquake near Sinabang (province of Aceh), on 7 April 2010, that was followed by a tsunami warning (but no tsunami), often referred to the warning as an "isu tsunami" (Indonesian for "rumor about a tsunami") rather than official information about a tsunami threat. This is related to the fact that official information was largely absent after the earthquake and rumours of a tsunami warning and people evacuating coastal areas spread, while, eventually, no (destructive) tsunami arrived at the coast. Very few media reports addressed the functionality of the system in a clear and comprehensive manner. This confirms that knowledge about TEW of news media personnel is still limited and their understanding of the system and the risk tends to be more similar to the public understanding than to the perspective of the NTWC personnel and disaster managers (Lindell et al., 2005). When explaining how the system works, public education activities need to make clear the limitations of the system with regard to the accuracy of initial warnings, and the fact that the first warning is the only information available that can be used to reinforce community response after an earthquake. Overstating what InaTEWS can do, or understating what it cannot do, will decrease trust in and credibility of the system in the long run.

Use the momentum of earthquakes, tsunami warnings and tsunami disasters to improve institutional capacities and educate the public. All public education prior to a disaster will not have the force of "one good disaster" to change what people think, their behaviour and public policy (Mileti et al., 
2004). The Aceh Tsunami in 2004 created momentum. People learned about natural warning signs. The Indian Ocean countries, including Indonesia, decided to develop national warning systems. The disaster also accelerated the reform of the Indonesian disaster management law and institutions. On a smaller scale, earthquakes (like in Padang on 30 September 2009, and Tasikmalaya on 3 September 2009) can accelerate preparedness planning and increase public understanding. However, while people and institutions are more apt to alter behaviours and improve capacities after a disaster, change is most likely when public educators and disaster management experts have already worked to make sure the problem is recognised and the way to improve preparedness is known (Mileti et al., 2004). National and local disaster research and management institutions as well as NGOs in Indonesia should make use of the "opportunities" created by earthquakes, tsunami warnings and tsunami disasters, to learn about people's behaviour, assess response capacity, support public discussion and provide recommendations for improvement to those in charge at national and local levels. Pro-actively approaching the media to clarify and explain the functionality of the system and the challenges with regard to warning services and appropriate response is equally important.

GTZ-GITEWS tackles this underlying lack of understanding of how the system works with awareness materials (including visual aids such as movies) and outreach activities. GTZ-GITEWS produced an information package for local decision- and policy-makers; a target group that is often difficult to reach but instrumental in assuring local leadership. Community level outreach activities, which have been implemented several times in various locations in Java and Bali, address the information needs of the population along the coast. Village meetings, supported by the project but implemented by local government representatives and communitybased facilitators, aim to bring together the technical and human factors in TEW and preparedness in order to build the "system" (GTZ-GITEWS, 2010).

\subsection{Developing local preparedness and TEW is a "group affair" that requires mutual cooperation and trust}

Tsunami disasters affect every sector of society. While TEW is a public service, preparing for future tsunamis and developing local TEW capacities and institutions that can effectively serve the people at risk needs to be a group affair. District, municipal and provincial governments have to provide the local framework of policies, legislation, procedures and preparedness plans as references for other stakeholders. Private sector representatives, from, for example, the particularly vulnerable tourism industry, need to get involved to raise risk awareness, share official preparedness plans and explore opportunities for cooperation and joint preparedness planning. Involving the media is important for both public education campaigns as well warning dissemination in case of emergency. Since the objective of TEW is to serve the people, preparedness activities need to involve the communities at risk or their representatives, i.e. local figures, NGOs or other civil society organisations. These representatives can bring the people's needs and expectations into the preparedness planning process. They are vital partners for building the bridge to the end users of the system. Advocacy and initiatives from these actors are crucial in accelerating the development of tsunami preparedness and early warning at the local level - especially if government structures are weak. Involving respected local people from government or civil society helps to increase the credibility of preparedness efforts, makes it easier to influence and provides access to local policy and decision makers and communities, brings in a variety of ideas, and means building a sustainable support network for long term preparedness efforts (GHI, 2008; GTZGITEWS, 2010; IFRC, 2009).

Developing local preparedness and TEW often depends on a few dedicated groups or individuals, both from government and civil society. These people face a dilemma: they are committed to develop TEW as a part of local preparedness; yet, they are often confronted with the problem of inadequate institutional structures to deliver TEW public services, as well as lack of political commitment. In the absence of public warning services at local levels, many civil society organisations have opted for and promoted a community-based approach to tsunami preparedness at grassroots level, which in many cases is based only on natural warning signs. This is a very reasonable option since a warning system that lacks local response capability on the part of disaster management institutions can hardly be perceived as beneficial to those at risk. However, the gap between technology-based TEW (as a public service) and community-based tsunami preparedness that relies on natural warning signs begins to close when institutional response capabilities are being developed. Ultimately, the question is not whether to opt for one or the other, but to integrate them into one consistent response strategy.

This dilemma can be overcome only with a persistent and joint effort that brings together all stakeholders. By no means is this effort - which aims to develop institutions, change minds and make disaster reduction a priority amongst so many others - a straightforward process. It is characterised by periods of success and progress, but also by setbacks and constraints - and it takes time. Examples from the GITEWS pilot areas illustrate the dynamics in three different locations and show progress in, and challenges for, implementing TEW locally. They also highlight how the various stakeholders start to engage in a closer cooperation once the early warning framework becomes clearer.

One and a half years after the devastating events of Aceh, on 17 July 2006, the Pangandaran Tsunami on 17 July 2006 brought destruction to the southern coast of Java and killed almost 700 people (Reese et al., 2007). This event reminded the public and the authorities that Java is equally prone to 
tsunamis, and created momentum for preparedness. The authorities of Bantul, Kebumen and Cilacap put up signboards and evacuation signs to raise awareness and inform people about tsunami behaviour. Driven by strong political commitment, the authorities of Yogyakarta and Bantul installed a total of eight locally developed sirens along the coast. However, when GTZ-GITEWS first started its work at the end of 2006, all pilot districts still lacked a systematic approach for tsunami preparedness planning and important inputs. The existing civil defence institutions focussed entirely on emergency response and struggled with human resources and budget constraints. From the beginning, the strength of the preparedness planning process in the pilot areas of Java was the continuous work of multistakeholder working groups. Originally appointed for the cooperation with GTZ-GITEWS, they filled the institutional gap and became local (and national) advocates for tsunami preparedness and TEW. A series of 15 workshops resulted in tsunami hazards maps, district evacuation plans, SOPs for decision-making and dissemination, and technical dissemination solutions. In 2008, the working groups and locally trained community-based facilitators conducted community outreach activities. As well as being able to provide general information about tsunami hazards, they were now capable to conduct village level evacuation planning (based on district evacuation maps) and to answer questions about local warning arrangements. At the same time, the three districts started to approach neighbouring districts and provincial authorities. The districts of Ciamis (province of West Java) and Purworejo (province of Central Java) joined the pilot project in 2009. The idea of the working groups creating a "tsunami forum" to build TEW and preparedness, and make use of synergies along the southern coast of Java (e.g. in terms of warning service), received regional and national attention both regionally and nationally. Inter-district and inter-province cooperation is perceived as a promising model for promoting TEW and preparedness across the administrative boundaries of tsunami prone regions. Considering the constraints faced by the working groups (including the lack of funds), a lot has been achieved through the piloting activities. However, the major challenge for the authorities in the next few years is to institutionalise the existing capacities and move from an approach of piloting to one of consistent long-term preparedness (GTZ-GITEWS, 2010).

In Padang, a team of individuals from various institutions, both governmental and non-governmental, today forms the backbone for local preparedness planning and the development of TEW. However, it took time to build cooperation and trust amongst the different stakeholders and to develop a shared strategy. After the Aceh Tsunami, it was a small group of volunteers in Padang that realised the tsunami risk for their city, who formed the NGO KOGAMI, started to advocate for tsunami preparedness and built success. (GTZGITEWS, 2010; GHI, 2008). In the absence of institutional capacities for a public warning service in Padang, KOGAMI built its response approach on natural warning signs. When GTZ-GITEWS started its cooperation with KOGAMI and the municipal government in 2006, the project gave priority to the development of procedures and technical solutions for warning dissemination in order to strengthen institutional capacities for TEW. However, reasonable doubt about the capability of local government institutions to provide public warning service remained. As a result of close cooperation, intensive discussions and an exchange of ideas in which different perspectives were acknowledged, the partners in Padang eventually developed a response strategy that is believed to match the needs of the approximately 230000 people of Padang (Taubenböck et al., 2009) who would be directly affected by a major tsunami. The response strategy in Padang, which was legalised by a mayor's decree (in April 2010), integrates the natural warning sign of strong ground shaking as the initial trigger for evacuation, and official alerts from the NTWC and local authorities to reinforce or cancel an ongoing evacuation. An additional important impulse for the joint effort in Padang came with the establishment of the city's BPBD in 2009 and its disaster operations centre in charge of TEW (GTZ-GITEWS, 2010).

In the aftermath of the Aceh Tsunami, BMKG installed a number of tsunami sirens along the southern coast of Bali. A tsunami drill in 2006, initiated by RISTEK, involved institutions and the community. However, the exercise had not much of an effect in terms of systematic and long-term preparedness planning by local institutions. GTZ-GITEWS engaged in cooperation with several working groups at province level, organised in accordance with the different components of local preparedness planning. But commitment was low and resulted in few tangible results. Besides an official tsunami hazard map (available since 2008), it was the strong political commitment to preparedness by the governor himself that eventually accelerated the planning process. The construction of the provincial emergency operations centre and the recruitment of skilled personnel (trained on procedures and technology) created momentum and ownership. Working groups at sub-district level, consisting of local representatives from both the government and communities, used the tsunami hazard map to develop evacuation plans for Kuta (district of Badung) and Sanur (city of Denpasar). The tourist island of Bali also provides an example of how the potential for cooperation between government, community and the private sector can be used. Cooperation between communities, hotels and civil society for tsunami evacuation shelter has proved to be an effective option for coastal tourism areas. In the event of a tsunami emergency, communities on the flat, sandy Tanjung Benoa peninsula in southern Bali would not be able to reach higher ground in time. The only viable option is vertical evacuation to existing buildings. The buildings that are strong and high enough to provide vertical evacuation shelter are those of the neighbouring hotels. As the result of a dialogue process facilitated by GTZ GITWES, the hotel sector in Tanjung 
Benoa now provides temporary evacuation shelter for the local communities at risk. Both parties agreed on clear procedures for temporary evacuation during tsunami warnings and emergencies. The Indonesian Red Cross supports local leaders in communicating the procedures to the population (Knight, 2010; GTZ-GITEWS, 2010).

\subsection{Tsunami hazard mapping: in search of the safe zone}

Understanding tsunami hazard and the assessment of possible impacts on their community are preconditions for local decision makers and other stakeholders to initiate activities and plans to get better prepared for future tsunami events. Tsunami hazard maps are the basis for evacuation planning. Maps showing the different zones allow for the identification of priorities and planning for differentiated action. These maps are also used as the basis for designing mechanisms (e.g. outreach and warning dissemination) for TEW at the local level.

Unfortunately, forecasting the probability and possible impact of a tsunami in a given area remains a major challenge. It is important to recognise that scientists do not have a complete understanding of the mechanisms that trigger tsunamis. As data are very limited and current estimations of return periods (for a single location) in Indonesia vary greatly, it is difficult to determine in a reliable way the probability of a tsunami of a particular magnitude occurring within a given period of time.

National and international scientific institutions adopt a range of approaches to tsunami hazard assessment in Indonesia, often employing different methodologies and data. As a result, a wide variety of tsunami hazard maps are circulating in the country. For certain locations, there are up to eight different maps (Padang), while other areas are not covered at all. Indonesia has yet to agree on a standardised methodology, and no lead agency has been appointed at national level to coordinate on this issue.

Communities need to develop clear frameworks for tsunami preparedness to ensure that activities implemented by the various actors follow the same overall strategy and do not contradict one other. Providing an official tsunami hazard map is definitely a priority task in achieving this goal. Local governments are in charge of providing official hazard maps for their own areas, but face a big dilemma: either they have to choose between a number of maps which provide different or even contradicting information, or they lack the necessary expertise to produce their own maps. The result is that, to date, most tsunami prone regions in Indonesia do not have an official tsunami hazard map.

Even with an official map on hand, the question of which areas are "safe" is not yet answered. Based on today's understanding of the hazard, local authorities must make a decision that involves choices, trade-offs and risk. The available time for evacuation is probably the most important factor.
Because of the infrequent occurrence of tsunamis and the limited data available for destructive tsunamis, information about possible impacts and run up heights is very uncertain. It must be assumed that no reasonable action can take into account all possible risk.

To enable local governments to make the necessary decisions, a dialogue mechanism was promoted, allowing scientists and local decision makers to work hand in hand. The project supported this "Science meets Politics" approach in Padang and Bali (GTZ-GITEWS, 2010).

The dialogue between politics and science in Padang started at the 2007 Padang Symposium, and was continued during the first meeting of the Padang Consultative Group in January 2008. The results from both events were then considered as inputs for the "Padang Consensus" that was defined during the 2008 Padang Symposium. The consensus consists of an agreement to base the Padang tsunami hazard map on a single scenario that is considered the most probable. The mapping will employ numeric modelling using source data as well as updated bathymetry and topography data provided and shared by the respective scientific institutions. Recently, this process came to an end. During the 2nd Padang Consensus meeting in April 2010, local stakeholders in Padang decided on an official tsunami hazard map for the city.

In Bali, a similar dialogue in August 2008 led to an agreement to adopt a multi-scenario approach and to the assignment of GITEWS partner institutions to develop the map for southern Bali. A local working group participated in the development process and presented the final product and a technical document to local decision makers. The map was officially approved in mid 2009 (DLR and GTZ, 2009).

In the pilot areas of Java, the situation was different because no hazard maps and only very little information from research were available in 2007 . The project decided to develop and test a simple, participatory and "low-tech" tsunami hazard mapping methodology that can be applied at the district level in order to provide local stakeholders with a better understanding of the local tsunami hazard and, in this way, create a basis for improving preparedness for future disasters. The approach, implemented in October 2007 in the districts of Bantul, Kebumen and Cilacap, aimed at developing a methodology and a learning process, together with representatives of local authorities and in cooperation with national experts. In addition to the primary outputs - a tsunami base and hazard map for each of the three districts and a validated methodology (that was documented in a guidebook; GTZ-GITEWS, 2010) - the exercise increased knowledge and awareness among the local participants about the potential tsunami threat along the southern coast of Java, and developed capacities to answer the question about "safe areas". The mapping methodology is currently being employed and further reviewed in the new pilot districts of Ciamis and Purworejo. 


\begin{tabular}{|c|c|c|}
\hline 1. Getting started & $\begin{array}{l}\text { Who? Mandate? } \\
\text { Timeframe? Resources? } \\
\text { Reference? }\end{array}$ & Work plan \\
\hline \multirow[t]{2}{*}{$\begin{array}{l}\text { 2. Elements to be } \\
\text { considered }\end{array}$} & \multirow{2}{*}{$\begin{array}{l}\text { Hazard \& safe zone, } \\
\text { evacuation routes, high } \\
\text { risk areas, vertical } \\
\text { evacuation shelters, } \\
\text { facilities requiring special } \\
\text { attention }\end{array}$} & \multirow[t]{2}{*}{$\begin{array}{c}\text { Map with all relevant } \\
\text { elements }\end{array}$} \\
\hline & & \\
\hline \multirow[t]{3}{*}{$\begin{array}{l}\text { 3. Defining strategies } \\
\text { for evacuation }\end{array}$} & $\begin{array}{l}\text { Horizontal \& vertical } \\
\text { options, triggers, support, } \\
\text { sign boarding }\end{array}$ & $\begin{array}{l}\text { Evacuation plan: } \\
\text { strategy, maps \& } \\
\text { procedures }\end{array}$ \\
\hline & $\begin{array}{l}\text { 4. How to } \\
\text { institutionalize } \\
\text { \& communicate? }\end{array}$ & $\begin{array}{l}\text { Implementation \& } \\
\text { dissemination plan }\end{array}$ \\
\hline & $\begin{array}{l}\text { 5. How to exercise } \\
\& \text { evaluate? }\end{array}$ & Exercise plan \\
\hline
\end{tabular}

Fig. 8. Five steps of evacuation planning.

\subsection{Evacuation planning - an attempt at a realistic approach}

Evacuation of people in risk areas is the first priority once a tsunami early warning is received and/or natural warning signs indicate the possibility of a tsunami. As the available time span between a warning and the impact of tsunami waves in Indonesia is generally very short, all necessary preparations need to be made in advance to ensure that as many people as possible get a chance to evacuate.

Research of available resources has shown that there is very little experience with evacuation planning for local tsunamis. A very useful resource is the guidebook "Preparing Your Community for Tsunamis" that was developed by Geo Hazards International (GHI, 2008). It provides practical steps for local advocates to identify safe locations, recommend evacuation routes, involve various stakeholders and produce local evacuation maps for the community level. In order to provide a practical tool to district and city governments in Indonesia, GTZ-GITEWS is currently drafting a guidebook that defines the cornerstones for evacuation planning to cope with local tsunamis and guides through the evacuation planning process (GTZ-GITEWS, 2010).

Tsunami evacuation planning covers the time span before and during a tsunami event. The primary objective is to get as many people as possible out of the reach of the waves to a "safe" or "relatively safe" area. "Relatively safe" areas are not necessarily located outside the inundation area and are unlikely to take the form of a single, central "temporary shelter area"; rather, they will be multiple locations (such as higher floors in buildings or land elevations), close enough to be reached in a short time. Contingency plans should foresee the need for additional temporary shelter areas to accommodate people and provide for their basic needs, including first aid, during a tsunami event, which usually lasts for several hours.

Tsunami evacuation plans and maps require official approval. Local disaster management planning is the responsibility of local governments. District plans and maps need enforcement through local government policy. A district or city evacuation plan is essential to provide officials and the community at risk with information and guidance. These official plans should serve as a reference to produce plans and maps at sub district levels: villages in rural areas and neighbourhoods in urban areas. The evacuation plans (i.e. maps and procedures) indicate hazard and safe zones, evacuation routes and shelter, dangerous bottlenecks (e.g. bridges and narrow streets), critical and vulnerable infrastructures, wellknown landmarks for orientation and the overall evacuation strategy including local warning arrangements. Though arrangement for traffic management should be made (Lindell et al., 2005), it should not be expected that much guidance or support from local emergency personnel will be available during the tsunami evacuation process. Individual, family, neighbourhood and institutional evacuation plans are needed to ensure that everyone is able to act independently, and as quickly as possible, as soon as an emergency arises. All the necessary steps have to be taken in advance to enable and support the community at risk to protect themselves, whether they are at home, at the work place, or in public spaces. Local 


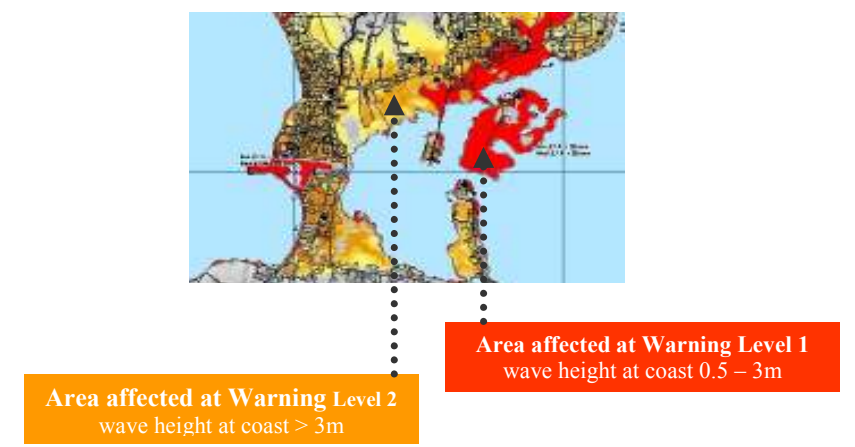

Fig. 9. Evacuation planning for different warning levels (DLR/GTZ, 2009).

governments should encourage and support the development of response plans and provide the necessary references to do so. Tsunami evacuation plans are probably the most important reference for preparedness if they are easy to understand and widely distributed.

The short tsunami wave arrival and warning times limit the evacuation time to only a few minutes. Due to the extremely short warning times for near field tsunamis, self-protection arrangements play a vital role. Research has shown that various factors influence individual and group response to warnings and evacuation behaviour (Sorensen, 2000). Understanding these factors that determine the capability to respond and perform appropriate life saving behaviour contributes to a better understanding of the community's overall vulnerability. Research in Padang for instance has identified knowledge of tsunamis, discussion about tsunami risk in the community, perception of people's vulnerability, knowledge of evacuation places, personal preference for safe places, self-efficacy in evacuation and doubt on tsunami early warning information, as important factors that influence the decision to evacuate and evacuation behaviour (Taubenböck et al., 2009). Evacuation after the earthquake in Padang on 30 September 2009 showed that many people did not immediately evacuate. Besides collecting valuables from their homes, seeking additional information or providing information to others, and protecting their property, their highest priority was to meet with their family before leaving the hazard area (Hoppe and Mahadiko, 2020; this behaviour has been described as "logistical and psychological preparation" by Lindell et al., 2005).

Emergency planners can primarily influence warning response by adjusting the design of the public alerting system (communication channels) and the wording of warnings and guidance messages to the needs of the people. Besides that, public education plays a major role (Sorensen, 2000). The evacuation planning process, both at district and sub-district level provides an opportunity to learn more about the community's response capacity, how they perceive their own risk and how they would react in case of emergency (or did in the past). A realistic strategy for evacuation is one that takes into account the capability of the people when determining evacuation routes and shelter areas.

Evacuation planning for future tsunami creates a momentum that can be used to educate people about tsunami risk as well as natural warning signs and early warning messages. Planning sessions can also be used to agree on local roles and responsibilities, e.g. with regard to warning dissemination in urban neighbourhoods or villages. Again, the planning process requires the participation of all stakeholders, in particular community representatives - since planning for future tsunamis means planning for those at risk.

GTZ-GITEWS implemented a five-step-approach to tsunami evacuation planning (see Fig. 8) in the pilot areas of Java and Bali. After the results of the implementation process have been evaluated this approach will feed into the above-mentioned guidebook (GTZ-GITEWS, 2010).

The 2004 tsunami set a new dimension for the "worst case scenario". The implications for evacuation planning are challenging, as the impacted area of the 2004 tsunami was up to ten times larger than the affected area of any historical, documented tsunami in Indonesia, with the exception of the Krakatau event. Evacuation planners face the dilemma of probability, as the worst case is a very rare event and evacuating people horizontally out of the potentially affected area is not realistic considering the short warning (arrival) times for near field tsunamis.

Another challenge for evacuation planners lies in the fact that, in the future, two warning levels will be introduced into InaTEWS (Fig. 9). In theory, this might help to solve the dilemma of the "worst case scenario", because decision makers will not necessarily have to call for full-scale evacuation if the threat is a minor one. On the other hand, the question arises of whether a two-level evacuation strategy is a realistic option when it comes to implementation. Considering the current state of public understanding of the warning system and the difficulties in disseminating warnings and guidance locally (Hoppe and Mahadiko, 2010; Taubenböck et al., 2009), the option of a two-level approach seems questionable. The experiences from the development of evacuation maps in Bali led to a discussion about the suitability of the warning levels and zones within InaTEWS. It was concluded that the zoning could distinguish between areas possibly affected by "average tsunamis" - occurring every two to three years - and "worst case events", occurring very rarely. This, however, requires adjustments in the parameters that define the warning levels. Even if this can be done, the two-level approach might create a false sense of the accuracy and certainty of warnings. The discussion with the NTWC and the German GITEWS partners is ongoing. Further consultation of the local partners on the feasibility of the two-level approach in the pilot areas is required. In Padang and in Cilacap, local stakeholders opted for a single-level evacuation strategy. 


\section{Conclusions}

The experiences from three years of local capacity development for TEW warning and preparedness in Indonesia reveal that implementing an end-to-end, and people-centred early warning system is a complex task. Implementation of the system requires a common understanding of the overall system on the part of all actors involved, political leadership, the will to cooperate, and committed and skilled individuals. Various experiences with recent earthquakes and tsunami warnings highlight the major effort that is required to close the "gap" between the system's technical achievements and its ability to actually benefit the people at risk and motivate them to take action. This effort requires a holistic and systemic view, focusing on upstream and downstream processes as well as local response capability in equal measure.

To make the system effective, the development of local response capability has to be addressed with same level of commitment and investment provided to the development of the technological components. Human capacities at all levels need to be developed to increase the institutional response capability at the local level. To build a common understanding of the system and to encourage all actors to accept and play their respective roles, the provision of sufficient funding, adequate capacity development and instructive guidelines is essential. Developing these guidelines is a multi-stakeholder task. Only a joint learning process can lead to a tailor-made warning chain and public outreach strategies that really address the needs of the community at risk. Results and experiences from this learning process need to be systematised and documented. Applying the existing experiences from the pilot areas to a larger number of regions along the tsunamiprone coastlines is a major challenge for the way ahead. Recent experience from an "exchange programme" advocates further promotion of a forum for cross-learning and capacity development, drawing on existing expertise from various regions, levels and sectors. Public education needs to clearly and openly (and continuously) explain how the system can help to save lives, indicating its strengths but not understating its limitations. Going public, explaining the system, using the "opportunity" that earthquakes and tsunami warnings (or disasters) can create, and building relations with the end users of the system - the communities at risk - is essential to building the trust in and credibility of the system that is required to achieve its ultimate goal: to save lives.

To make the system sustainable, it needs to be institutionalized at all levels. Clarifying institutional arrangements and developing strong institutions at national and local level needs to go hand in hand with the technical advancement of the system. The provision of sufficient long-term funding is part of this as well as the integration of TEW as a component of DRR into long-term national and local disaster management and development plans. The DRR as well as the end-to-end concept of TEW were only recently introduced in Indonesia. The transition to DRR involves changing mind- sets and developing institutions, such as BNPB. This still requires a great deal of advocacy both at national and local levels to convince the relevant actors to embrace the concept of risk reduction. The Indonesian institutions that have been involved in the development of the system together with other players in the field of DRR need to continue to pro-actively promote InaTEWS.

\section{Appendix A}

\section{Abbreviations}

AusAID The Australian Government's Overseas Aid Program

BMBF German Federal Ministry of Education and Research - Bundesministerium fuer Bildung und Forschung

BMKG Badan Meteorologi Klimatologi dan Geofisika (National Agency for Meteorology, Climatology and Geophysics)

BNPB Badan Nasional Penanggulangan Bencana (National Disaster Management Agency)

BPBD Badan Penanggulangan Bencana Daerah (Regional Disaster Management Agency)

DAC Development Assistance Committee of the OECD

DKP Departemen Kelautan dan Perikanan (Ministry of Marine Affairs and Fisheries)

DLR The German Aerospace Center Deutsches Zentrum fuer Luft- und Raumfahrt e.V.

DRR Disaster Risk Reduction

GFZ German Research Centre for Geosciences - Deutsches GeoForschungsZentrum, Potsdam

GITEWS German Indonesian Tsunami Early Warning System

GTZ Deutsche Gesellschaft für Technische Zusammenarbeit (German Technical Cooperation)

IFRC International Federation of the Red Cross and Red Crescent Societies

InaTEWS Indonesian Tsunami Early Warning System

InWEnt Internationale Weiterbildung und Entwicklung (Capacity Building International, Germany)

IOWave09 Indian Ocean Wave Exercise 2009

KOGAMI Komunitas Siaga Tsunami (Tsunami Alert Community) 


$\begin{array}{ll}\text { LIPI } & \begin{array}{l}\text { Lembaga Ilmu Pengetahuan } \\ \text { Indonesia (Indonesian } \\ \text { Institute of Sciences) }\end{array} \\ \text { NOAA } & \begin{array}{l}\text { National Oceanic and Atmospheric } \\ \text { Administration (USA) }\end{array} \\ \text { NTWC } & \text { National Tsunami Warning Centre } \\ \text { OECD } & \text { Organisation for Economic } \\ & \text { Cooperation and Development } \\ \text { RISTEK } & \text { Kementrian Negara Riset } \\ & \text { dan Teknologi (State Ministry } \\ & \text { for Research and Technology) } \\ \text { TEW } & \text { Tsunami Early Warning } \\ \text { TEWS } & \text { Tsunami Early Warning System } \\ \text { UNDP } & \text { United Nations Development } \\ & \text { Programme } \\ \text { UNESCO-ICG } & \text { United Nations Educational, } \\ & \text { Scientific and Cultural } \\ & \text { Organization - Intergovernmental } \\ & \text { Coordination Group } \\ \text { UNESCO Jakarta Tsunami } & \text { Information Centre } \\ \text { UNECSO-JTIC } & \text { United Nations International } \\ \text { UNISDR } & \text { Strategy for Disaster Reduction } \\ & \text { United States Agency for } \\ \text { USAID } & \text { International Development } \\ & \end{array}$

Acknowledgements. The GITEWS project (German Indonesian Tsunami Early Warning System) is carried out through a large group of scientists and engineers from different German research institutes under the leadership of the GFZ, German Research Centre for Geosciences. Funding is provided by the German Federal Ministry for Education and Research (BMBF), Grant 03TSU01. The authors would like to thank national partners in Indonesia, RISTEK and LIPI, as well as the various partners in the GITEWS pilot areas, the local governments, civil society organisations, and private sector representatives for their fruitful cooperation over the years.

We are grateful to the Australian Government (AusAID) for additional funds. The authors also thank the GITEWS management and the other GITEWS partners. "Capacity Building in Local Communities" would have not been possible without the support of a great team: and the authors would like to express their appreciation for the contributions of all who are or have been actively involved in the project.

We would like to thank the reviewers and the editor, who helped to improve the quality of our manuscript.

Edited by: A. Rudloff

Reviewed by: B. G. McAdoo, C. E. Gregg, and

J. C. Villagran de Leon

\section{References}

CSO: The DNA code of risk has two intertwined strands - why vulnerability matters: a civil society response to the draft guidelines for Disaster Risk Assessment in Indonesia 2009, result of CSO-Consultation Meeting on Position Paper Concerning National Guidelines for Disaster Risk Assessment of BNPB in Bali, Indonesia, 2008.

DLR and GTZ-GITEWS: Technical documentation - tsunami hazard map for southern Bali. Presented by Balinese Working Group for Tsunami Hazard Mapping, compiled by DLR and GTZ, avalable at: www.gitews.org/tsunami-kit (available online by the end of 2010), 2009.

GHI (Geo Hazards International): Preparing your community for tsunamis: a guidebook for local advocates, Contributors: Samant, L. D., Tobin, L. T., and Tucker, B., working draft 2.1, available at: www.geohaz.org/news/images/publications/ Preparing YourCommunityforTsunamisVersion2-1.pdf (last access: 1 June 2010), 2008.

GITEWS: Official website of GITEWS, available at: www.gitews. org, 2010.

Gregg, C. E., Houghton, B. F, Paton, D., Johnston, D. M., Swanson, D. A., and Yanagi, B. S.: Tsunami warnings: understanding in Hawai' I, Nat. Hazards, 40, 71-87, 2007.

GTZ: GTZ's understanding of capacity development - a guiding framework for corporate action, available at: www.gtz.de (last access: 1 June 2010), 2007.

GTZ: Good governance and decentralization programme, available at: www.gtz-decentralization.or.id (last access: 1 June 2010), 2010.

GTZ IS-GITEWS: Tsunami Kit for local capacity development within InaTEWS, available at: www.gitews.org/tsunami-kit (available online by the end of 2010), 2010.

Hamzah, L., Puspito, N. T., and Inamura, F.: Tsunami catalog and zones in Indonesia, Journal of Natural Disaster Science, 22-1, 25-44, 2000.

Hoppe, M. and Mahadiko, H. S.: 30 minutes in Padang - lessons for tsunami early warning and preparedness from the earthquake on 30 September 2009. GTZ-GITEWS project publication (circulated via email), available at: www.gitews.org/tsunami-kit (available online by the end of 2010), 2010.

IFRC: World disasters report 2009 - focus on early warning, early action, available at: www.ifrc.org/publicat/wdr2009/index.asp? navid=09_03, (last access: 1 June 2010) 2009.

InWEnt: Workshop media: peran media dalam ranati sistem peringatan dini bencana, workshop report, Jakarta, 2009.

IOWave09: Official website of the IOWave Exercise, available at: www.iowave09.org/index.php, 2010.

JTIC (Jakarta Tsunami Information Centre): Undangundang Republik Indonesia nomor 24 tahun 2007 tentang penanggulangan bencana, available at: www. jtic.org/index.php?option=com_content $\backslash \&$ view=article $\backslash$ \&id=352\%3Auu-penanggulangan-bencana $\backslash \&$ catid $=73 \%$ 3Aarticles-a-newsletters \\&lang=en, last access: 1 June 2010.

Knight, L.: Being prepared in case of a tsunami could save your life, feature article in the Bali Advertiser, available at: www. baliadvertiser.biz (last access: 1 June 2010), 2010.

KOMPAS: Listrik padam, sirene tak berbunyi, Kompas Daily Newspaper on 7 September 2009. 
Kunz-Plapp, T.: Vorwarnung, Vorhersage, und Frühwarnung, Naturrisiken und Sozialkatastrophen, edited by: Felgentreff, C., Spektrum Akademischer Verlag, Berlin, 213-224, 2008.

Lassa, J.: Warning system is about people, The Jakarta Post, available at: www.thejakartapost.com/news/2008/11/27/ warning-system-about-people.html (last access: 1 June 2010), 2008a.

Lassa, J.: When heaven (hardly) meets the earth: towards convergency in tsunami early warning systems, in: Proceeding of Indonesian Student's Scientific Meeting, Delft, The Netherlands, www.zef.de/module/register/media/ d614_Lassa-Tsunami-Early-Warning-System.pdf (last access: 1 June 2010), 2008b.

Lindell, M. K., Prater, C. S., and Peacock, W. G.: Organizational communication and decision making in hurricane emergencies, prepared for the Hurricane Forecast Socioeconomic Workshop, Pomona, California, available at: www.sip.ucar.edu/pdf/02_Communications_and_Organizational_ Decision_Making_for_Hurricane_Emergencies.pdf (last access: 1 June 2010), 2005.

McAdoo, B., Moore, E. A., and Baumwoll, E. J.: Indigenous knowledge and the near field population response during the 2007 Solomon Islands Tsunami. Nat. Hazards, 48, 73-82, 2009.

Mileti, D., Nathe, S., Gori, P., and Greene, M.: Public hazards communication and education: the state of the art, update of Informer Issue 2: Public Education for Earthquake Hazards, available at: http://userweb.port.ac.uk/ simgilesd/Documents/ Geohazards\%20WP/nhc_informer2update.pdf (originally published in 1999), 2004.

OECD: The challenge of capacity development: working towards good practice, DAC reference document, DAC Guidelines and Reference Series, 2006.

OECD: The Paris Declaration and Accra Agenda for Action, available at: www.oecd.org/document/18/0,2340,en_2649_3236398_ 35401554_1_1_1_1,00.html (last access: 1 June 2010), 2010.
Reese, S., Cousins, W. J., Power, W. L., Palmer, N. G., Tejakusuma, I. G., and Nugrahadi, S.: Tsunami vulnerability of buildings and people in South Java - field observations after the July 2006 Java tsunami, Nat. Hazards Earth Syst. Sci., 7, 573-589, doi:10.5194/nhess-7-573-2007, 2007.

Rudloff, A., Lauterjung, J., Münch, U., and Tinti, S.: Preface "The GITEWS Project (German-Indonesian Tsunami Early Warning System)", Nat. Hazards Earth Syst. Sci., 9, 1381-1382, doi:10.5194/nhess-9-1381-2009, 2009.

Sorensen, H.: Hazard warning systems: review of 20 years of progress. Natural Hazards Review, 1(2), 119-125, May 2000.

Taubenböck, H., Goseberg, N., Setiadi, N., Lämmel, G., Moder, F., Oczipka, M., Klüpfel, H., Wahl, R., Schlurmann, T., Strunz, G., Birkmann, J., Nagel, K., Siegert, F., Lehmann, F., Dech, S., Gress, A., and Klein, R.: "Last-Mile" preparation for a potential disaster - Interdisciplinary approach towards tsunami early warning and an evacuation information system for the coastal city of Padang, Indonesia, Nat. Hazards Earth Syst. Sci., 9, 1509-1528, doi:10.5194/nhess-9-1509-2009, 2009.

Thomalla, F., Larsen, R. K., Kanji, F., Naruchaikusol, S., Tepa, C., Ravesloot, B., and Ahmed, A. K.: From Knowledge to Action: Learning to go the last mile - a participatory assessment of the conditions for strengthening the technology-community linkages of tsunami early warning systems in the Indian Ocean. Stockholm Environment Institute, Project Report, 2009.

UNISDR: Developing early warning systems - a checklist, output of the Third International Conference on Early Warning (EWC III) held in Bonn, Germany, 2006.

Usdianto, B.: Learning from the Earthquake and Tsunami Warning on 2 September 2009: Results of a Rapid Assessment of Institutional and Community Response, internal report by GTZGITEWS, 2009. 